6. Петрик Л. Методичні можливості застосування медіазасобів на уроках іноземних мов. URL: https:// library.udpu.edu.ua/library files/probl sych vchutela/ 2014/10_2/8.pdf.

7. Равен Дж. Компетентность в современном обществе. Москва, 2002. 218 с.

\section{REFERENCES}

1. Horwitz, Yu.M., Chaynova, A.A. \& Podiakov, N.N. (1998). Novye informacionnye tehnologii v doshkolnom obrazovanii [New information technologies in preschool education]. Moscow, 328p. [in Russian].

2. Loginova, A.V. (2015). Preimushchstva ispolzovaniya prilozheniya Google Docs v obuchenii inostranimu yazyku [Benefits in using Google Docs application in teaching foreign languages]. Junior scientist. No.8, pp. 976-979. Available at: https://moluch.ru/archive/88/17423 [in Russian].

3. Maslov, V.I. (2004). Strategicheskoe upravlenie personalom $v$ uslovijah jeffektivnoj organizacii kultury [Strategic personnel management in the conditions of effective organization of culture]. Moscow, 288p. [in Russian].

4. Ovcharuk, O.V. (2003). Kompetentnosti jak kljuch do formuvannja zmistu osviti [Competence as the key to the formation of the content of education]. Strategy of reforming education in Ukraine. Kyiv, 295p. [in Ukrainian].

5. Pedagogichnyi Slovnyk (2001). [Pedagogical dictionary]. (Ed.). Yarmachenko. Kyiv, 363 p. [in Ukrainian]. 6. Petryk, L.V. Metodychni mozhlyvosti zastosuvannya mediazasobiv na urokah inozemnyh mov [Methodological opportunities for using media during English classes]. Available at: https://library.udpu.edu.ua/library files/ probl sych vchutela/2014/10 2/8.pdf. [in Ukrainian].

7. Raven, J. (2002). Kompetentnost $v$ sovremennom obshhestve [Competence in Modern Society]. Moscow, 218 p. [in Russian].

Стаття надійшла до редакції 07.06.2019

УДК 373.5.013:316.614.3./5

DOI:

Василь Кизенко, кандидат педагогічних наук, провідний науковий співробітник відділу дидактики Інституту педагогіки НАПН України

\title{
ФЕНОМЕН СОЦАЛЬНОЇ СФЕРИ ЯК ДЕТЕРМІНАНТА ПРОЦЕСУ ФОРМУВАННЯ І РЕАЛІЗАЦІЇ ЗМІСТУ КУРСІВ ЗА ВИБОРОМ ДЛЯ УЧНІВ СТАРШОЇ ШКОЛИ
}

Актуальність порушеної проблеми трунтується на ідеях, меті, організації процесу навчання і виховання, особливостях профілізації сучасної старшої школи і феномені суспільства як мірила якості життєдіяльності особистості. 3 урахуванням тенденцій розвитку теорії змісту шкільної освіти теоретично обтрунтовується зміст курсів за вибором, акцентується аксіологічний аспект професійного становлення, суб 'єктного досвіду особистості учня старшої школи у сочіально-педагогічній системі.

Ключові слова: старша школа; профільне навчання; курси за вибором; соціалізація особистості. Jim. 14.

Vasyl Kyzenko, Ph.D.(Pedagogy), Leading Researcher of the Didactics Department, Institute of Pedagogy of NAPS of Ukraine

\section{PHENOMENON OF THE SOCIAL SPHERE AS DETERMINANT OF THE PROCESS OF FORMATION AND REALIZATION OFTHE CONTENT OF ELECTIVE COURSES FOR UPPER SECONDARY SCHOOL PUPILS}

The urgency of the problem is based on the ideas, goals, organization of the process of education and upbringing, on the features of profiling of modern upper secondary school and on the phenomenon of society as an indicator of the quality of vital activity of the individual. The author is theoretically substantiating the content of elective courses, noting that it is necessary to take into account the trends in the development of the theory of the content of school education. He believes that the axiological aspect of the content of elective courses influences the professional formation, the subjective experience of the personality of upper secondary school pupil in the system of social and pedagogical relations.

In the content of profile education, it is important to actualize the perspective needs of society, to motivate the educational needs of children, and to teach correlation of these inquiries with the requirements of production spheres or individual production, as well as the needs stemming from social relations. Social, pedagogical and content components directly affect the management activities of institutions of general secondary education. Management, respectively, must be understood as a complex spiritual and social phenomenon of human life, as a distinct cognitive system.

Clarification requires the theoretical and methodological approaches to the development of all aspects of subject preparation of pupils within the limits of the invariant and variable educational components. The profilization 


\section{ФЕНОМЕН СОЦАЛЬНОӤ СФЕРИЯК ДЕТЕРМІНАНТАПРОЦЕСУ ФОРМУВАННЯ І РЕАЛЗАЦЇ ЗМІСТУ КУРСІВ ЗА ВИБОРОМ ДЛЯ УЧНІВ СТАРШОЇ ШКОЛИ}

of a modern Ukrainian school (including social partnership) requires a didactic rethinking of the phenomena of the social sphere, which reacts to the results of scientific and technological progress. The organization of the educational process in institutions of general secondary education depends on a large extent on the transformational processes taking place in the information society. A characteristic feature of the educational sector is the consistent development and improvement of the content of the courses of choice, in accordance with the traditional and new specialties that are offered now to entrants. It should effectively affect the functioning of the mechanism for managing cognitive and educational activities of pupils, influencing the processes of formation and socialization of upper secondary pupils at the preprofile and profile preparation stage.

Keywords: upper secondary school; profile education; elective courses; socialization of personality.

П остановка проблеми. Шкільну освітню систему водночас можна і слід розглядати як систему соціальнопедагогічну - коли йдеться про мету, цілі, завдання, технології і кінцевий освітній результат про випускника закладу загальної середньої освіти, підготовленого до входження у соціум 3 його вищими системами освіти, а ще виробничими, соціальними, культурними, громадянсько-правовими відносинами тощо.

Оскільки жодна з означених систем не існує у чистому вигляді, то соціально-педагогічні детермінанти правлять у кожній із них. Тож феномен соціальної сфери загалом підсилюється не тільки освітніми, а й виробничими, соціокультурними, громадянсько-правовими та іншими чинниками, викликаними життям суспільства і діяльністю кожної особистості зокрема. Соціально-педагогічні детермінанти, серед іншого, не мисляться поза рефлексійною культурою здобувача освіти. Рефлексійна культура, на наше переконання, розвивається у підлітків ефективніше, якщо варіативна складова змісту освіти старшої школи формується 3 урахуванням інтересів учнів, здібностей і життевих намірів, уявлюваних перспектив функціонування у соціумі, професійних і власне життєвих успіхів, пов'язаних з рідним краєм чи іншими регіонами України.

Зміст курсів за вибором для учнів старшої школи нині також становить серйозну дидактичну проблему, оскільки сучасна трендовість профільного навчання ніби відмежовується від завдань, покладених на курси за вибором відображати у своєму змісті економічні, етнічні, історичні, соціокультурні особливості регіону, де живугь і навчаються діти, та інші суттєві елементи формування у підростаючого покоління світогляду, правової та екологічної свідомості, патріотичних почуттів і т.ін., що не розкриваються інваріантним предметним змістом.

Аналіз досліджень і публікацій. Суспільство у широкому сенсі - це сукупність певних відносин, що пов'язують людей у процесі матеріального і нематеріального виробництва і відтворення їх матеріального і духовного життя; сукупність форм спільної діяльності людей, які склалися історично. Суспільство $є$ особливим, найвищим ступенем розвитку живих систем, який виявляється у функціонуванні й розвитку соціальних організацій, інститугів, груп тощо [9]. Тож природовідповідне суспільство - мірило якості життєдіяльності особистості. А зміст освіти як система наукових знань про природу, про суспільство, про мислення людини позначається на всеможливих аспектах життєдіяльності людини. Отже, і зміст освіти має бути природовідповідним, а особливо - зміст курсів за вибором для учнів старшої школи, тобто - відображати соціальний досвід. У змісті профільної освіти важливо актуалізувати перспективні потреби суспільства, мотивувати освітні запити дітей і навчати співвідносити ці запити з вимогами виробничих сфер чи окремих виробництв, а також потребами, зумовленими соціальними відносинами. "Суспільство наділило школи безліччю обов'язків, з якими школи справляються за допомогою інструментів, наданих навчанням і освітою. Співробітники школи повинні мати на увазі, що в цьому світі, який стає все більш індивідуалізованим, вони у своїй професійній ролі уособлюють обов'язки, надані їм суспільством" [8, 122 - 123].

Соціальні, педагогічні і змістові складові чинять безпосередній вплив на управлінську діяльність закладів загальної середньої освіти. Управління, відповідно, маємо розуміти не як інструментально-технологічну діяльність, прерогатива якої вичерпується питаннями адміністративного чи/або організаційного характеру, а як складнішого духовно-соціального феномена людської життєдіяльності, самобугньої когнітивної системи.

Управління покликане відігравати роль ефективного способу взаємозв'язку соціокультурної теорії та практики перетворень знаннєвої парадигми, тому розв'язання питання про своєрідність і механізм дії управління як форми зв'язку теоретичних моделей і практичних рішень постає, крім того, ще й як дієвий засіб взаємоузгодження теорії та практики вже у царині самої управлінської діяльності [12; 13]. I саме за такої постановки питання феномен соціальної 
сфери усвідомлюється як детермінанта процесу формування і реалізації змісту курсів за вибором для учнів старшої школи.

Мета статті - окреслити детермінанти процесу формування і реалізації змісту курсів за вибором для учнів старшої школи; схарактеризувати феномен соціальної сфери та його кореляційний вплив на профільне навчання у закладах загальної середньої освіти.

Виклад основного матеріалу. Головною ідеєю сучасної освіти в усіх концепціях розвинених країн є ідея створення адаптивного освітнього середовища для становлення юної особистості, а відтак - формування повноправного члена суспільства. Зміни в цінностях вітчизняної освіти відбуваються на всіх рівнях ii функціонування. Провідними стають не засвоєння формальних знань і навичок, а гуманність стосунків, свобода самовиявлення, культивація індивідуальності, творча самореалізація особистості. Це конкретизується меті загальної середньої освіти, що передбачає створення умов для всебічного розвитку індивідуальності дитини на основі виявлення iï задатків і здібностей, виховання ії як громадянина України, національно свідомої, демократичної, життєво і соціально компетентної особистості. Одним із ключових напрямів реформування шкільної освіти є диференціація навчання, тобто такий навчальний процес, для якого характерні врахування індивідуальних особливостей учнів, їх глибоке вивчення, виокремлення на цій основі типологічних груп $\mathrm{i}$ організація їх діяльності за допомогою конкретних методів, часткових прийомів та обгрунтованого застосування дидактичних технологій реалізації курсів за вибором в умовах профільного навчання. Зміст таких курсів - також компонент процесу навчання, це - також система емоційно-ціннісного ставлення до світу як до багатокомпонентного об'єкта, а також розвиток профільнодиференційованих інтересів із метою соціалізації та максимальної самоактуалізації особистості $[11,170]$.

Повертаючись до питання рефлексійної культури учасників освітнього процесуі освітнього середовища закладів загальної середньої освіти загалом (соціально-освітній аспект), укотре наголосимо на соціально-педагогічній системі. Так от. Виняткового значення упроцесі соціалізації особистості старшокласників набуває формування їх рефлексійної культури.

Актуальність профілізації сучасної школи. На сучасному етапі соціальноекономічного розвитку країни актуалізуються питання профілізації закладів загальної середньої освіти. Увідповіднення змісту шкільної освіти запитам суспільства, зміна професійнокваліфікаційної структури кадрів 3 урахуванням потреб ринку праці і вимог до якості підготовки фахівців детермінують перегляд концептуальних засад освіти учнів передусім за допрофільної підготовки i профільного навчання. Тож потребують уточнення принципові теоретикометодологічні підходи до розроблення всіх аспектів предметної підготовки учнів у межах інваріантного і варіативного освітніх компонентів. Профілізація сучасної української школи (у т.ч. соціальне партнерство) потребує дидактичного переосмислення феноменів, якими проявляє себе соціальна сфера, реагуючи (захопливо, утруднено, бездумно) на продукти науково-технічного прогресу та їх позитивний вплив і наслідки, що можуть мати незворотний характер, усвідомлюється як детермінанта процесу формування і реалізації змісту курсів за вибором для учнів старшої школи. Оскільки ми згадали і про соціальне партнерство, то, передусім, наголосимо на соціальній значущості думок різних сторін щодо багатьох аспектів профілізації старшої школи. Сюди віднесемо анкетування учнів на етапі допрофільної підготовки, проведення опитувань серед батьків, функціонування шкільних веб-сайтів, моніторинг Інтернет-ресурсів закладів вищої освіти з метою вивчення пропозицій щодо продовження навчання 3 метою здійснення аналітичного прогнозу щодо можливостей задоволення освітніх потреб майбутніх абітурієнтів тощо.

Актуальність організації процесу навчання і виховання. Організація освітнього процесу у закладах загальної середньої освіти значною мірою залежить від трансформаційних процесів, що відбуваються в інформаційному суспільстві. Характерною ознакою освітньої галузі $\epsilon$ послідовне розроблення й удосконалення змісту навчальних курсів за вибором відповідно до традиційних і новітніх спеціальностей, які пропонуються нині абітурієнтам. Це має ефективно позначатися на функціонуванні механізму управління пізнавально-навчальною діяльністю учнів, впливаючи на процес становлення й соціалізацію учнів на етапі допрофільної і профільної підготовки.

Однак, за висновками науковців, структурна i змістова інтеграція загальної і професійної освіти ще не набула чітких абрисів, а організаційні і педагогічні умови забезпечення діяльності профільної школи недостатньо викристалізувалися, то й навчально-професійна діяльність учнів носить епізодичний (несистемний) характер. Тобто, навчання, хоч і спрямоване на забезпечення 


\section{ФЕНОМЕНСОЦАЛЬНОӤ СФЕРИЯК ДЕТЕРМІНАНТАПРОЦЕСУ ФОРМУВАННЯ РРЕАЛІЗАЦІІ ЗМІСТУ КУРСІВ ЗА ВИБОРОМ ДЛЯ УЧНІВ СТАРШОӤ ШКОЛИ}

професійного у майбутньому зростанні, не знаходить бажаної (адекватної) рефлексії $[2,19]$.

Шкільна освіта: тенденції розвитку теорї̈; професійне становлення здобувача освіти; різновиди спеціальних курсів. Зважаючи на основні функції сучасної освіти (соиіалізаційна - навчання, виховання і розвиток дитини, в результаті яких вона буде підготовленою до активного, самостійного життя в суспільстві; людиностворююча - збереження і відтворення екології людини, ії тілесного та духовного здоров'я, особистої свободи, сенсу життя, створення умов для ії розвитку і самореалізації; культуротворча збереження і трансляція, відтворення і розвиток культури, сприяння національній i загальнолюдській культурній ідентифікаціі), не можна не говорити про тенденції розвитку теорії змісту шкільної освіти на початку XXI ст. А це, за О. Савченко: поєднання соціального запиту i потреб особистості при доборі змісту освіти; збагачення і конкретизація процесуальної частини змісту освіти завдяки дидактико-методичному розробленню нових способів навчальної взаємодії вчителя і учнів, домінантою яких $\epsilon$ опанування дітьми продуктивних способів діяльності; уведення до змісту освіти особистісного компонента, задля формування мотиваційноціннісних якостей учнів і набуття ними життєвого досвіду; переосмислення і переструктурування компонентів змісту освіти (знання про людину, природу, суспільство, культуру, техніку; уміння й навички (розумові та практичні, загальнонавчальні та предметні); досвід творчої діяльності; система цінностей, ставлень, поведінки людини) на засадах компетентнісного підходу; уведення середовища до компонентів змісту освіти, що зумовлено інформаційною насиченістю макро- i мезосередовищ, які активно чи пасивно впливають на пізнавальний і мотиваційноціннісний складники навчання [10].

Оскільки зміст освіти (у т.ч. зміст курсів за вибором) становить педагогічно адаптований соціальний досвід, тому має складатися 3 відповідних йому структурних складників, кожен із яких відтворює певний специфічний досвід. Оскільки соціалізація особистості відбувається у сферах діяльності, спілкування й самосвідомості, доцільно говорити про такі компоненти змісту шкільної освіти - інформаційно-діяльнісний, комунікативний та рефлексійний. Тож зміст сучасних курсів за вибором для учнів старшої школи має бути однією з педагогічних умов, яка через оволодіння системою світоглядних i соціально значущих знань забезпечує формування у старшокласників досвіду ціннісно-орієнтаційної, пізнавальної, соціальної, комунікативної, естетичної, фізичної діяльності та допоможе розкрити їх індивідуальні особливості, визначити інтереси, нахили й забезпечити розвиток здібностей.

За С. Гончаренком [3], процес професійного становлення особистості передбачає: a) пропедевтичне ознайомлення з інтересами, нахилами і здібностями учня; б) допрофільну підготовку, основна мета якої полягає у формуванні в учнів здатності робити свідомий вибір подальшого профілю навчання; в) профільне навчання, яке реалізується за одним із передбачених навчальним планом профілів; г) соціалізацію випускників завдяки звуженню діапазону професійного вибору, визначенню альтернативи соціалізації, адаптації до умов життя і діяльності в колективі співробітників (упродовж двох - трьох постшкільних років).

За пріоритетними дидактичними завданнями, що реалізуються спеціальними курсами, виокремлено і схарактеризовано певні різновиди ïx. Серед них: спеціальні курси, що спрямовуються на поглиблене й розширене вивчення окремих розділів профільних загальноосвітніх предметів або не віднесених до змісту такої програми; спеціальні курси, що розкривають професійнопрактичний аспект знань, здобутих у процесі вивчення базових і профільних предметів; спеціальні курси, які ознайомлюють учнів із новими галузями знань, не представленими у змісті базових і профільних предметів, але зорієнтованим на можливу майбутню професію за обраним профілем навчання; спеціальні курси 3 наукових основ сучасних виробництв і технологій; спеціальні курси міжпредметного узагальнювального характеру, які на основі інтеграції у процесі шкільного навчання знань завершують формування цілісних природничо-наукової і соціально-гуманітарної картин світу; спеціальні курси, спрямовані на забезпечення допрофесійної i початкової професійної підготовки старшокласників.

У класичному розумінні, формування навчального курсу за вибором у змісті профілю передбачає насамперед процес наукового опису тих чи тих об'єктів і внесення їх як елементів до структури навчального курсу [5]; аналіз досліджуваних об'єктів має співвідноситися 3 інваріантним змістом [6]. Тож основні елементи моделі змісту навчальних курсів, предметів мають відтворювати інформацію про систему предметних знань, умінь і навичок, досвід творчої діяльності й моральні якості особистості [7] йдеться про вміння інтеріоризувати ціннісні 


\section{ФЕНОМЕН СОЦАЛЬНОЇСФЕРИЯК ДЕТЕРМІНАНТАПРОЦЕСУ ФОРМУВАННЯ РЕАЛІЗАЦЇ ЗМІСТУ КУРСІВ ЗА ВИБОРОМ ДЛЯ УЧНІВ СТАРШОЇ ШКОЛИ}

орієнтації, а також трансформувати алгоритмізовані дії під час розв'язання типової навчальної задачі; аналізувати навчальну ситуацію відповідно до особливостей ії виявів і контекстних реалізацій.

Окремі години варіативної частини Базового навчального плану можуть використовуватись для реалізації регіонального освітнього компонента, зміст якого відображає національну, економічну, природничо-географічну, соціокультурну своєрідність регіону, його історію, традиції й інші відомості, які не увійшли або недостатньо відображені у змісті загальнодержавного освітнього компонента, але є суттєвими для формування світогляду, патріотичних почуттів, необхідні для повноцінного входження підростаючої особистості в життя в умовах певного регіону.

Як зазначають науковці, необхідно зберігати, розвивати, збагачувати й примножувати поціновані у світі вартісні ознаки освіти, що стосуються традицій освіченості як ментального складника нації. Також слід актуалізувати вітчизняні здобутки з дидактики, лінгводидактики, освітології, порівняльної педагогіки, водночас вивчаючи можливості перспективних для української освіти зарубіжних моделей із проекцією на національне підгрунтя [1].

Висновки. Гострота порушеного питання полягає в тому, що на соціально-професійному самовизначенні українських старшокласників негативно позначаються суперечності - між соціально-економічними універсаліями демократичної країни ігромадянськогосуспільства (правосуб'єктність, свобода конкуренції, відсутність монополії, плюралізм ідей, незалежність особистості тощо), 3 одного боку, та тенденційними категоріями вітчизняної ринкової системи господарювання, що глобалізується (брак ідеї єдиної держави, економічний і психологічний примус, матеріальне й духовне зубожіння населення, нехтування соціальною цінністю громадян тощо), з іншого. Тож маємо визнати: теперішня учнівська молодь сприймає традиційні для українців гуманістичні ціннісні орієнтації крізь призму цілераціональності й утилітарного практицизму [4, 38]. Окреслені детермінанти процесу формування і реалізації змісту курсів за вибором для учнів старшої школи, схарактеризований феномен соціальної сфери та його кореляційний вплив на профільне навчання у закладах загальної середньої освіти це ті відправні точки, що змушують переглядати дидактичну систему профільної освіти. Наразі шкільна освітня система стає чутливішою до проблем суспільства, набуває ознак системи соціальнопедагогічної. Відповідно, зміст курсів за вибором для учнів старшої школи постає як серйозна дидактична дилема: всеціло і безапеляційно підтримувати сучасну трендовість профільного навчання, яке, до речі, ще аморфне, чи неупереджено й послідовно відображати у своєму змісті економічні, етнічні, історичні, соціокультурні особливості та перспективи життєдіяльності підростаючого покоління за нових світоглядності, правової та екологічної свідомості, де патріотичність та аксіологічність почуттів піддаються викликам сучасного глобалізованого світу 3 його геополітичним та ціннісними ризиками.

\section{ЛІТЕРАТУРА}

1. Бондаренко Н. В., Косянчук С. В. Українська мова у фокусі перспектив реформування старшої школи. Молодь і ринок. 2018. №4 (159). С. 8692.(doi: https://doi.org/10.24919/2308-4634.2018.131492).

2. Васьківська Г., Косянчук С. Організаційнопедагогічні умови профільного навчання. Молод $b$ і ринок. 2013. №5(100). С. 19-24.

3. Гончаренко С. У. Педагогічні закони, закономірності, принципи. Сучасне тлумачення. Рівне, 2012. 192 с.

4. Кизенко В. Постнекласична раціональність новітня методологічна проблема профорієнтаційної діяльності профільної школи. Біологія і хімія в рідній школі. 2018. № 4. С. 37-43.

5. Краевский В. В. Научное исследование в педагогике и современность. Педагогика. 2005. № 2. С.13-20.

6. Краевский В. В., Лернер И. Я. Процессы обучения и его закономерности. Дидактика средней школы : некоторые проблемы совр. дидактики / под ред. М. Н. Скаткина. Москва, 1982. С. $129-180$.

7. Леднев В. С. Содержание образования: сущность, структура, перспективы. Москва, 1991. $224 \mathrm{c}$.

8. Покка А. Вищий клас. Шкільне управління по-фінськи. Пер. з англ. О. М. Назарової. Харків, 2017. $160 \mathrm{c}$.

9. Рубинштейн С. Л. Проблемы общей психологии. Москва, 1976. 416 с.

10. Савченко О. Розвивальний потенціал змісту освіти у 12-річній школі. Освіта. 2008. №15/16.916 квіт.

11. Самодрин А. П. Організація діяльності профільно-диференційованоїсередньої загальноосвітньої школи : дис. ... канд. пед. наук. Кривий Ріг, 1998. $198 \mathrm{c}$.

12. Стрельніков В. Ю. Теоретичні засади проектування професійно-орієнтованої системи (підготовка бакалаврів економіки). Полтава, 2005. 329 с. 
13. Токарук Л. С. Організаційно-адаптивне управління навчально-виховним процесом у загальноосвітніх школах-інтернатах : дис. ... канд. пед. наук. Київ, 2007. 215 с.

\section{REFERENCES}

1. Bondarenko, N. V. \& Kosianchuk, S. V. (2018). Ukrainska mova u fokusi perspektyv reformuvannya starshoi shkoly [The Ukrainian language in the focuses of prospects for reforming the upper secondary school]. Youth \& market. No.4 (159). pp. 86-92. (doi: https://doi.org/10.24919/ 2308-4634.2018.131492). [in Ukrainian].

2. Vaskivska, H. \& Kosianchuk, S. (2013). Orhanizatsiino-pedahohichni umovy profilnoho navchannya [Organizational and pedagogical conditions of specialized education]. Youth \& market. No.5(100). pp. 19-24. [in Ukrainian].

3. Honcharenko, S. (2012). Pedahohichni zakony, zakonomirnosti, pryntsypy. Suchasne tlumachennya [Pedagogical laws, regularity, principles. Modern interpretation]. Rivne, 192 p. [in Ukrainian].

4. Kyzenko, V. (2018). Postneklasychna ratsionalnist - novitnia metodolohichna problema proforiientatsiinoi diialnosti profilnoi shkoly [Postnonclassical rationality as the latest methodological challenge of career guidance in terms of a specialized school]. Biology and Chemistry in native school. No. 4. pp. 37-43. [in Ukrainian].

5. Krayevskiy, V. V. (2005). Nauchnoye issledovaniye $v$ pedagogike $i$ sovremennost [Scientific research in pedagogy and a modernity]. Pedagogy. No. 2. pp. 13-20. [in Russian].

6. Krayevskiy, V. V. \& Lerner, I. Ya. Protsessy obucheniya i yego zakonomernosti. Didaktika sredney shkoly: nekotoryye problemy sovr. didaktiki [Learning processes and his laws. High school didactics: some problems ofmodern didactics]. (Ed.).M. N. Skatkina. Moscov, 1982. pp. 129-180. [in Russian].

7. Lednev, V. S. (1991). Soderzhaniye obrazovaniya: sushchnost, struktura, perspektivy [Education content: essence, structure, perspectives]. Moscov, 224 p. [in Russian].

8. Pokka, A. (2017). Vyshchiy klas. Shkilne upravlinnia po-finsky [Higher class. Management of School on the Finland]. Kharkiv, 160 p. [in Ukrainian].

9. Rubinshteyn, S. L. (1976). Problemy obshchey psikhologii [Problems of general psychology]. Moscov, 416 p. [in Russian].

10. Savchenko, O. (2008). Rozvyvalnyi potentsial zmistu osvity u 12-richnii shkoli [Educational potential of the content of education at a 12-year school]. An education. No.15/16. 9-16 April [in Ukrainian].

11. Samodryn, A. P. (1998). Orhanizatsiia diialnosti profilno-dyferentsiiovanoi serednioi zahalnoosvitnioi shkoly [Organization of the profiledifferentiated secondary comprehensive school]. Candidate's thesis. Kryvyi Rih, 198 p. [in Ukrainian].

12. Strelnikov, V. Yu. (2005). Teoretychni zasady proektuvannia profesiino-oriientovanoi systemy (pidhotovka bakalavriv ekonomiky) [Theoretical principles of designing a professionally-oriented system (preparation of bachelors of economics)]. Poltava, 329 p. [in Ukrainian].

13. Tokaruk, L. S. (2007). Orhanizatsiinoadaptyvne upravlinnia navchalno-vyhovnym protsesom u zahalnoosvitnih shkolah-internatah [Organizationaladaptive management of the educational process in general-education boarding schools]. Candidate's thesis. Kyiv, 215 p. [in Ukrainian].

Стаття надійшла до редакції 07.06.2019

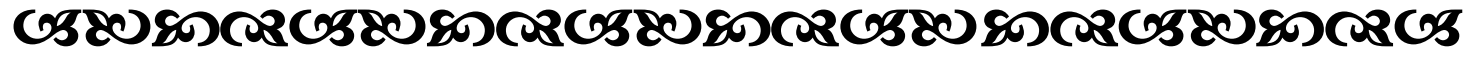

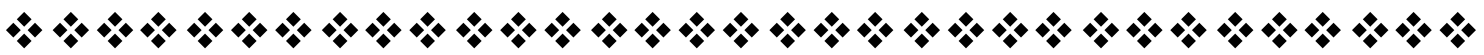

“Серйозне прагнення до будь-якої мети - вже половина успіху в ї̈ досягненні". Вільгельм Тумбольдт німецький білолог, бьілособ

"Світ постає перш за все яК неперервний розвитокминулого, яқе вбирає в себе майбутнє та розширюється в міру руху вперед”.

Анрі Бергсон

французький білособ

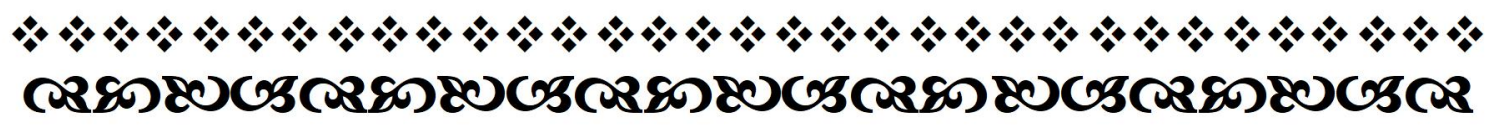

